NBER WORKING PAPER SERIES

ASSESSING CLINTON'S PROGRAM ON

JOB TRAINING, WORKFARE, AND EDUCATION

IN THE WORKPLACE

James Heckman

Working Paper No. 4428

NATIONAL BUREAU OF ECONOMIC RESEARCH

1050 Massachusetts Avenue

Cambridge, MA 02138

August 1993

This paper is part of NBER's research program in Labor Studies. Any opinions expressed are those of the author and not those of the National Bureau of Economic Research. 
NBER Working Paper \#4428

August 1993

\title{
ASSESSING CLINTON'S PROGRAM ON JOB TRAINING, WORKFARE, AND EDUCATION \\ IN TIIE WORKPLACE
}

\begin{abstract}
The Clinton admigistration has made job training and skill upgrading a major priority. Secretary of Labor Robsert Reich his ulready presented a bold program for skill entancement drawing on a new consensus in certain circles of the social science and policy communities about lie need to upgralle the nation's skills. An apparently new approakh to training and cducation hus been proposed and Secretary Reich is now busy selling it to the Congress and the Nation.

This paper provides background on the problems in the labor market that motivate the new Clinton-Reich initiatives on training ant schooling. [1 brielly summatrizes the proposed strategries and the buckground philosoply for the Clinton-Reich agenda. It then considers the evidence that supports or contradicts assumptions of their plan. There is a lot of evidence about many of the "new" proposals because some are reworked versions of old prograns that have been cartully evaluated. Other proposals borrow idess from Germany. I compire tle rletoric thit accompanies these proposils in the context of the U.S. labor market. Still other proposils have ber evaluated in demonstration projects but the lessons from these evaluations have not yet in lidemed : administration thimking. This is unfortulate becalus many current plans ure based on assumplions that have been discredited in carcful empirical studies. This resedrch has not yet caught the attention of the policy makers in Washington.

Jarnes Heckruldr:

Depirtment of Ecumonics

Universicy of Chicatgo

1129 E. 59 h Street

Chicugo, IL 60637

and NBER
\end{abstract}




\section{Some Undeasant Arithmetic About The Iron Law of Skill Investments}

A central fact dominating the Clinton administrations' concems about the labor market is the declining real income of male high school graduates and high school dropouts. In purchasing power constant or deflated dollars, male high school graduates earn $4 \%$ less per week in 1989 than in 1979. Male high school dropouts eam $13 \%$ less per week than in 1979. Male coilege graduates eam $11 \%$ more per week. These comparisons widen further if we consider annual eamings. By any measure, labor incomes have become more unequally distributed.

For women, the story is somewhat different. Real wages of female high school graduates have risen but the rise has been even greater for fermafe college graduates. Thus for both men and women, inequality of labor incomes has risen. The retums to schooling and skill have increased. The real earnings of workers at the bottom of the skill distribution (less than high school graduate) have definitely declined for persons of either gender. Youth have been hit hardes: in this shifting market for skills. Indeed, it is the youth labor market that is a central focus of concern for the Clinton policies.

A corollary phenomenon is the decline in labor market activity especially among the unskilled. Using a variety of labor force measures, we find that among the unskilled there is much greater joblessness, nonemployment and longer unemployment spells than among workers with more skills. This gives rise to the "Youth Labor Market Problem" - a central focus of cument policy concem. Particularly problematic are the less skilled (high school degree or less) youth who appear to flounder in the market for years before they settle down. These youth are a source of major social problems. Teenage pregnancy, participation in crime, incarceration, and idieness are important phenomena that are on the increase in most areas. 
The problen of a deteriorating market for unskilled or semiskilled workers is not solely a problem of youth. Displaced adults - primarily factory workers-are a major concem. Efforts to retrain the so called "dislocated workers" are central to the Clinton agenda. Middle-age workers displaced from high-wage manufacturing jobs are at a major disadvantage in the new market for labor that has emerged since many of these workers took their first jobs. The decline of manufacturing has displaced many workers with substantial investments in unwanted skilis.

This new inequality with declining real incomes for the unskilled is a central fact of our time and is a major concern of the Clinton administration. The employment and training component of Clinton's stimulus package was designed to address these problems. Roughly $\$ 16.5$ billion dollars was set aside to upgrade American skills. Even though the stimulus package was defeated, its major components are still very much under consideration in administration circles.

Before considering specific features of Clinton's program, I furst describe the size of the tusk confronting his administration. My analysis will confim the impression that economics is a dismal science because my calculations convey very dismal information indeed.

In his budget speech, President Clinton frequently used the term "investment" to describe his plans for job training. He was referring to investment in human capital - the skills of persons - in cescribing the job investment program. An investment generally yields retums over many years, after initial costs are incurred. For human capital, a round - and roughly correct - average number is $10 \%$. Thus, for each $\$ 10$ invested in a person, the expected average return is $\$ 1$. Some claim that this number is lower and some claim that it is higher but most economists would accept a $10 \%$ retum as a good starting point for the kind of analysis I want to present. 
Table 1

Estimated Investment Outlays Required To Restore

1979 Parities and Levels in The Labor Market

(1989\$)

\begin{tabular}{|c|} 
Assumed Rate of Return: $10 \%$ \\
\hline $\begin{array}{c}\text { A. To Restore Male High School Dropouts to 1979 Real Wage Levels } \\
=\$ 284 \text { Billion }\end{array}$ \\
(\$25,000 per high school dropout adjusted for labor force \\
participation) \\
B. To Restore Male High School Graduates to 1979 Real Wage Levels \\
$=\$ 501.5$ Billion
\end{tabular}

Source: Statistical Abstract of the United States, 1990 . The figures adjust for differentia rates of labor force participation. The figures for wage differentials come from Rebecca Blank, Employment Strategies: Public Policy To Increase The Work Force and Earnings", Harvard University Press, forthcoming in 1994, edited by Sheldon Danziger, Gary Sandefur, and Daniel Weinberg, working title, "Poverty and Froblice Policy: What Do We Know? What Should We Do?" 
To add \$1,000 in earnings per year to the average person, it is necessary to make a one time investment of $\$ 10,000$ in that person. This is a large sum but many college students are making even greater investments each year. Using a $10 \%$ rate, I can take any annual earnings gap and determirie how much investment must be done to close it simply by multiplying the gap by ter.

What do such colculations teveal? Consider two interesting counterfactual questions:

(1). How much would we have to invest in our workforce in $\$ 1989$ to restore male high school dropouts to their 1979 real incomes?

This question is meaningful only for men because real weekly wages for women have risen or remained roughiy constant over the period 1979-1989.

A second question is:

(II). How much would we have to invest in our workforce in $\$ 1989$ to restore 1979 differentials without reducing the real income of anyone (those for dropouts vs, high school graduates; high school graduates vs, persons with college; dropouts vs. persons with college)?

Answers to these and other related questions are given in Table 1. The answer to question 1 is a staggering $\$ 284$ Billion. Thus, if all of the $\$ 16.5$ billion of the Clinton stimulus package had been devoted to upgrading the skills of the workforce to restore male 1979 real earnings, if would have gone less than $6 \%$ of the way toward restoring high school dropouts to their previous positions in the labor market.

The answer to question II is more dismal yet. To restore skill differentials to their real I979 levels would take more than two trillion 1989 dollars. This would require an enormous 
effort. At the proposed rate of expenditure it would take 124 years to achieve this objective. The other calculations in Table 1 indicate the magnitude of the investment required to restore real wages to their 1979 positions.

One could qualify these calculations in many ways. One might want to adjust down the rate of retum as more difficult-to-train persons receive training. Or, one might wish to account for the fact that as persons are upgraded from high school graduate status, the real incomes of the remaining high school graduates are likely to increase. Under most plausible scenarios the costs of restoring skill parities to their 1979 levels are huge.

From these calculations, we learn two lessons: (a) the problem addressed by the Clinton administration is an enormous one and (b) expenditures at the level of 16 - or 60 - billion dollars a year cannot possibly solve these problems in the next four years. These sobering conclusions also suggest that it will be essential to make wise investments. With resources as limited as they are, it is necessary to make the most effective use of them.

\section{The General Principles Guiding The Clinton-Reich Initiatives}

In the past four years, a consensus of sorts has emerged in certain circles about the functioning of the U.S. labor market and the institutions that produce skills for that labor market and in that labor market. It is negative in tone about current institutions and looks abroad especially to Norhem Europe - and in particular Germany - for advice on how to structure American labor market policies. Nathan Glazer has recently summarized the intellectual sources for the new view and so a detailed review of the origins of these ideas is not needed. ${ }^{1}$

The foilowing core ideas underlie the new consensus. 
(1) The growing inequality in wages and incomes is a serious social problem. Especially troublesome is the decline in real eamings among young and unskilled workers.

(2) The quality of the labor force is in decine. Included in the notion of "quality" is the work ethnic, artitude, etc, of employees. The U.S. is perceived to be facing a skills shortage exacerbated by immigration from countries with less skilled workers. Our productivity growth has declined and this is linked to the decline in the quality of our labor. The recent growth in output during the Reagan-Bush years had more to do with expansion of inputs (primarily the surge of workers produced by the Baby Boom) rather than with workforce quality improvements.

(3) The procuctivity of the workforce cannot be improved by investing in physical capital and machinery because "low wage countries can now use the same machines and still sell their products more cheaply than we can". (This view is not held universally even within the group of scholars advocating the new view).

(4) The key to enhanced productivity lics in a "Third Industrial Revolution now taking place in the world": Henry Ford-style mass production and specialization (also known as "Taylorism" after its synthesizer and formalizer the incustrial engineer frederick Taylor) is becoming obsolete, although it is still widely utilized in the United States. The ability to produce quality goods, sensitive to changing consumer tastes - "flexible technology" - is what is valued now and this requires more highly trained - not necessarily more highly specialized - workers. Participation in the "global economy" requires that we move toward high productivity work organizations built around highly trained workers.

(5) American schools have failed to produce high-quality students. They fail to motivate students and leave students inadequately trained for açademic or nonacademic altematives. Most 
A merican education is only poorly connected in content or practicality with the demands of jobs. The low academic performance of Americans is manifest in poor test scores compared with those of other countries.

(6) As a consecuence of the point just made, the "school to work" transition in America is "chaotic" compared to the "orderly", "smoothly functioning" transitions experienced by German youth. Youth apprenticeships, especially designed for non-academically-oriented youth motivate learning by making it tangible. They will make leaming relevant to market needs and will foster as environment of achievement among the non-academically-oriented youth. By certifying youth through nationally recognized credentials based on tests, we will do for vocational training what we currently do for academic training by granting rationally recognizable and accepted degrees. We will enhance incentives for acquisition of skills in the workplace "by guaranteeing" an economic retum to quality in a national market through establishment of nationally-recognized skill credentials programs operated by firms, unions and govemments. In this way, we will create the skili base for Americans to participate in the "Third Industrial Revolution".

The new consensus is a happy marriage of two recent lines of thought: (a) The view that the craft economy - the "flexible technology" economy - more adaptable to taste and technology change is coming back after a century and a half of the triumph of the mass production economy. This view was expounded by Michael Piore and Charles Sabel ${ }^{2}$ and has fired the imaginations of many planners and policy makers. It has proved hard to document as a widespread phenomenon but "flex-tech" is widely trumpeted as the "leading edge" technology; and (b) The view that a rew to the apprenticeship system that supported the old craft system 
will provide the incentives to acquire the right skills. This view is most avidly espoused by Stephen Hamilton ${ }^{3}$. To this line of thought has recently been adjoined a third argument that "Fex-tech" is best implemented in job environments in which firms and unions cooperate, and in which workers with general skills perform a multiplicity of tasks. It is claimed that by defying the law of comparative actvantage and by foregoing the benefits of specialization in tasks in the workplace, worker and firm productivity will be enhanced. Coupicd with the remarkable and unsupported claim that investment in physical capital cannot restore or boost American productivity in regard to other countries, the new consensus virtually dictates a strategy of workplace - based investment in human capital.

To these views are added the more prosaic, and ongoing, concem that most Americans share about the welfare population. President Clinton made a bold promise during the last presidential campaign to train workers for two years and then induce them to work by reducing their welfare benefits. In addition to this promise, the Clinton team proposed that dislocated adult workers - who have lost their jobs by plant and firm closings - should be retrained to leam new jobs.

I now turn to the specific features of these proposals.

\section{Clinton's Specific Agenda For Training}

The Clinton Program has the following features and approximate price tags. Here, I use the old proposals withdrawn in April as a benchmark for likely new proposals.

- The Summer Youth Employment and Trairing Program under the Job Training Partnership Act (JTPA) to doubled in size from 700,000 slots to 1.4 million slots at an 
increased cost of $\$ 1$ billion for the first year of operation.

- President Clinton's National Service Program would be started as a pilot program at a cost of $\$ 15$ million.

- The Sertor Community Serviçe Employment Program, which provides part-time work for older Americans, would be increased by $\$ 33$ million to serve an additional 5,000 older workers.

- A Worker Proffing project would be undertaken to assist states in developing automated systems to identify laid-off workers likely to experience difficulty in obtaining a new job. Development costs are estimated to be $\$ 14$ million.

- A Qne-Stop Career Shopping Program would be established to provide adults interested in upgrading their skills or changing careers with a single location where they could apply for services needed. The program would cost $\$ 900$ million over four years.

- A Welfare Reform initiative will be developed to help families in poverty gain the skills and cducation needed to increase their incomes. Details have not been developed, but the program will provide enhanced education and training for up to two years, after which welfare recipients will be required to work.

- The Trade Adjustment Assistance (TAA) Program and Economic Dislocation and Worker Adjustment Assistance (EDWAA or Title III of JTPA) would be combined and expanded to serve more dislocated workers who lose their jobs due to foreign competition, industry restructuring, and defense downsizing. The program would likely cost \$2 billion in 1997 and approximately $\$ 4.6$ billion over 4 years.

- The Job Corps would be expanded by 50 percent by 2001 to increase slots from 70,000 
to 104,000 . The cost would be $\$ 202$ million in 1997 and $\$ 341$ million for $1994-97$. An additional $\$ 50$ million in 1997 and $\$ 105$ milion over four years would be used to renovate existing Job Corps centers.

- The Summer Youth Employment and Training Pogram would be expanded on a permanent basis to provide more employment, education, and training opportunities for disadvantaged youth. Over four years, the expansion would cost $\$ 2$ billion and provide an additional 2 million summer opportunities.

- A nationwide systern of Youth Aporenticeship programs would be established to provida school - and work-based leaming for youth who do not plan to attend college. The proposal calls for $\$ 500$ million in 1997 and $\$ 1.2$ billion over four years.

\section{How Effective Are These Programs Likely To Be?}

\section{A. The Summer Youth and Employment Training Program}

The investrent content of the Summer Youth Employment and Training program is likely to be low. Predecessor programs like the Kennedy-Yohnson Neighborhood Youth Corps program were well known to be palliatives, designed to keep inner city youth out of the streets. No firm evidence of any lasting effects of these programs on the employment, wages, criminal or sexual behavior has ever been demonstrated. The new rwist on this program is that an "investment" argument has been given to it. Barbara Heynes and her associates have argued that knowledge acquired in schoots deteriorates through disuse during the summer." The new proposals recognize this possibility and suggest that summer youth programs should be exhanced by learning enrichment activities. "Make work" has become an "investment". 
What are the prospects for success of this progran? Fortunately, a recent cvaluation of the Summer Training and Education Program (STEP) has been presented by Public/Private Ventures, a Philadelphia-based non-profit corporation that evaluates and manages social policy initiatives aimed at helping disadvantaged youth.

STEP offered two summers of employment, academic remediation and a life skills program to low-achieving 14 - and 15 - years old from poor families. The objective was to reach youth at the crucial age at which they are deciding whether or not to drop out of school or become pregnant. Part-time summer work at the minimum wage was supplemented with remedial reading and math classes and courses on the fong term consequences of drug use, unprotected sex, and dropping out behavior.

Using randomized trials, 4,80014 - and 15 - year olds in five cities were enrolled into or randomized out of the program. Both treatments and controls were followed for eight years. A high quality evaluation was conducted using state of the art "Demonstration Methods" for three cohorts of participants.

The outcomes of this program are disappointing. STEP participants experienced measured short run gains and boosted their math and reading scores by half a grade as measured by competency tests. Even after 15 months, these gains held up, but gains in the second summer were less than those in the first. Especially large was short-run growth in knowledge of contraceptive methods.

This short-term promise did not translate into longer-term gains. Three and a half years after their STEP experience - at the ages of 17 and $18-15 \%$ of participants were neither at work nor at school. The proportions were virtually identical for treatments and controls. Some 
$22 \%$ of young women had children and $64 \%$ of these were receiving public assistance in some form. Work rates and school completion rates were identical and low for treatments and controls. ${ }^{5}$

Since STEP is, if anything, more intensive than the proposed summer youth programs, this evidence suggests that summer youth programs are not investments. There is no evidence that they have lasting effects on participants. They may, however, protect the peace, prevent riots and lower the summer crime rate but there is no evidence of such effects.

\section{B. Youth Apprenticeship Programs}

I now tum to the most novel - and controversial - part of the Clinton-Reich agenda - the proposal for Youth Apprenticeship programs. Apprenticeship - once a vital part of the craft system - has now withered away. It is now largely confined to a few crafts in the construction trades. Participants in these programs tend to be in their mid-to-late twenties. The term "apprenticeship" is used more broadly in the new proposals advanced by the administration to encompass a variety of work-place-based training programs for youth in their late teens.

The premise of the Youth Apprenticeship Program is that in the American labor market the transition from school to work is "chaotic" with many youth who do not continue on to coilege becoming engaged in "deadend" jobs that lead nowhere. A recurrent theme in the policy discussions on this topic is that high youth tumover is a symptom of "floundering" in which aimless job search produces no long run benefit for youth labor market participants. In contrast, the German system is held up as paradigm of "order" in which youth in their late teens progress smoothly from school to work and engage in leaming on the job. Much lower youth 
unemployment and nonemployment-nonschooling rates in Germany are contrasted favorably with high rates in the United States. ${ }^{\circ}$

The central features of the German scheme that are advocated for adaptation to an American setting are:

(1) Workplace-based training and schooling which will motivate learning for the less academically inclined. By putting theoretical constructs developed in the classroom to immediate use on the shop floor, students who are not academically oriented will be more likely to learn new ideas of perceived immediate value. This is the "motivation to learn" argument.

(2) Workplace-based training reduces job shopping by linking trainees to firms at an early age. It increases knowledge of the world of work and facilitates acquisition of knowledge about the world of work. Instead of wasting time searching for a job, apprentices are busy learning how to do a job. This eliminates a lot of unnecessary search. This is the "cuts wasteful search" argument.

(3) Workplace-based training places young people in contact with nonfamily adults earlier than traditional schooling and teaches the work ethnic. It takes students out of formal schoois where peer pressure often works to undermine learning and achievement. This is the "eliminates peer pressure and promotes exposure to adults" argument.

(4) Workplace-based training improves on ordinary vocational training provided in public schools which is often out of touch with market realities and new ideas. Firms providing training are more likely to be in touch with market denands than are public school bureaucracies. This is the "benefit to privatization of learning" argument although it is rarely described in these terms by advocates of Youth Apprenticeship programs. 
(5) Workplace-based training coupled with national certification for achievement of skills by govemmental, industry and union groups will bring to vocational training the benefits of credentialling now conferred by academic degrees and certificates. Certification of generallyrecognized skills will create a national market for skills that are cumently hard to verify. Workers will have a greater incentive to invest in skills if they can transport them to a wide variety of firms. This is the "credentialling" argument.

(6) Workplace-based training will be the First step in a lifetime of career learning in which workers retum to the classroom on a regular basis to enhance skills. Learning will become a permanent part of the workplace eliminating the sharp dichotomy between learning and eaming that characterizes the current labor market. This is the "career of leaming" argument.

What are the merits of these arguments? Before answering this question, it will be helpful to summarize existing knowledge about the youth labor market in the United States and to examine the functioning of the German apprenticeship program.

\section{(i) The Youth Labor Market in America}

Comparing the United States and German labor markets, there can be no doubt that the latter is more "orderly" in the sense that a much smaller proportion of youth is not at work or not at school in Germany at age 17 than in the United States. This fact does not prove that the German system is the more efficient one. This is especially true in light of the fact that the compulsory schooling age is 18 in Gemany while it is 16 in most states in the United States. Most German youth are required to be "off the street" at the ages when young Americans are making their transitions to full-time jobs.

The technocratic view put forth by advocates of youth apprenticeship programs deny the 
value of job shopping and job search that characterizes the United Stales labor market. Joblessness and tumover are viewed as wasteful activities that are usefully curtailed. Yet a recent study documents the important role of job shopping as an element of career mobility for young male workers (over age 18) in the American labor market. During the first ten years of labor force attachment, a typical male worker holds seven jobs and achieves about one third of his realized wage growth by changing jobs. (Career paths for young women have not been studied in similar detail). Matching of workers to firms - characterized by the consensus view as a time-intensive process that involves "wasteful" search and "wasteful" tumover - is in face a major source of productivity enhancement with important long tem economic and social consequences. $^{*}$

Such matching activity is productive because the worker skills utilized by firms are idiosyncratic. A bright person with a corrosive personality may not be suited for one firm but may be idea! for another. Diversity is an inlegral reature of the skills embodied in persons. Diversity of opportunities in firms is an essential feature of the American economy. Job shopping is a productive activity that reveals the suitability of worker-firm matches.

Morcover, finding a successful match is only the beginning of the investment process that characterizes most worker-firm relationships. There are match-or firm-specific investments that enhance productivity and are not portable elsewhere. No uniform national skill test can certify or predict the value of these investments in advance. It takes trial and error to learn about, create and expand upon good matches. Programs that "certify" general skills do not recognize the enormous economic value of nontransferable match-specific skills. The credentialling argument biases government policy toward general skills because they are easier to measure. 
Much research demonstrates that standardized tests are only crude proxies for the skills that are valued by firms. The goal of using uniform national tests to eliminate "wasteful" job shopping by certifying skills is likely to be an illusory one. More information is preferred to :ess information and skill tests probably convey some information. They cannot convey ail of the characteristics of personality, notivation, and drive that make for a successful worker and a successful match nor can they capture important firm-specific skills.

The case for certifying skills diminishes under close scrutiny. The technocratic point of view that youth job tumover is a "wasteful" activity is not supported by the evidence Job shopping promotes wage growth. Tumover is another form of investment not demonstrably less efficient than youth apprenticeships.

The concern about "inefficient" joblessness that is characteristic of recent proposals for youth apprenticeships also ignores some important features of the youth labor market summarized by Richard Freeman, David Wise, Martin Feldstein, David Ellwood and Hary Holzer. First, most ( $83 \%$ ) teenagers (men and women age 16-19) are either in school, working or both. Most unemployed teenagers are either in school or seeking only part-time work. Only $6 \%$ of all teenagers are unemployed, out of school and looking for full-time work. Most leenage unemployment spells are short. The bulk of teenage unemployment is experienced by a small group of tenagers with long spells of unemployment. These teenagers are concentrated in disadvantaged (minoricy, poor family background) groups with low levels of education. The unemployment and nonemployment problems are very acute for high school dropouts. This is, however, only a small portion of the total teenage population. Deadend joblessness is not a modal phenomenon for teenagers - rather, it is a phenomenon for only a minority of them. The 
recent (1980') growth in joblessness and length of unemployment spells documented has been neutral across age groups. The $1970^{\prime}$ view that unemployment risk declines with age remains. essentially correct today.

Some employment problems are concentrated among a small proportion of youth with disadvantaged backgrounds. Black youth are less likely to be employed than are white youth. Early employment experience has little effect on later employment chances controlling for ageinvariant person-speciñc characteristics. Loss of work experience reduces wage growth but such effects are transient in the life cycle. Even when teenagers hold deadend jobs, most transit out of them by the early twenties. There appear to be few "permanent scars" (in the language of David Ellwood) from early "floundering" or job shopping during the teenage years and in the longer view, there is considerable evidence of wage growth that results from job shopping.

None of this denies that there are disadvantaged groups that are not readily assimilated in labor makkets. Special remedies may be appropriate for these groups. Apprenticeship and special job training programs may be appropriate for them. But in devising national strategies for revising education and training, it is also important to keep in mind the broader picture of the youth labor market. "Chuming" is a form of leaming and most youth who are in deadend jobs work and search their way out of them.

\section{(ii) How The German Apprenticeship System Works}

German youth move through three academic tracks. By grade 4 or 6 students are sorted into three schools: Hauptschūle where they continue until grades 9 or 10; Realschutle where they continue until grade 10; and Gymnasium where they continue until grade 13. Hauptschüle leads 
to apprenticeships usually of a three year duration. Typically, one day a week of an apprenticeship is spent in academic schooling suitable to the occupation being trained for. The rest of the apprentice's time is spent leaming and working on the job. Realschüle qualifies studertts for further vocational schooling that eventually culminates in work and learning ("dual system") activities. Gymrasium leads to university preparation and is technically considered outside of the apprenticeship system although in certain sectors, such as banking, students certified to go to the university instead take a forn of professional apprenticeship. Hauptschüler become carpenters, auto mechanics and office assistants. Realschüler become laboratory technicians, precision mechanios and personnel managers. They are placed in higher level apprenticeships. Not all graduates of these schools become apprentices. (Only $38 \%$ of Realschūler become apprentices and about $50 \%$ of the Hauptschüler become apprentices.) Many youth, especially those from Realschüler, continue on in post-secondary vocational schools. Government pays for the schooling. Apprentices pay the costs of training by taking lower wages.

Apprenticeship wages range from 22-33\% of full-time professional wages. The training wage varies by sector with larger firms paying more than smaller firms and in the hand crafts sector (retail trade and services) wages are quite low. Many apprentices live at home and are unable to support themselves with the apprenticeship wage. Only $10 \%$ of the firms in industry and commerce paricipate in these training programs, while $40 \%$ of the smaller crafts firms participate at the lower wages they face. These training wages thus operate like youth subminimum wages. Since the German economy is virtually $100 \%$ unionized, the variance from high level urion wages granted apprentices greatly facilitates their employment. The 
apprenticeship system thus provides an escape route for firms from high union wages.

Apprentices are tested for minimal knowledge of basic skills. The pass rate on certification exams is $90 \%$. Candidates may take the exam twice more if they fail the exam on the first attempt. Success rates in the exams thus tend to be quite high. Most apprentices move on to take full-time positions at other firms. This is especially true for trainees in the crafts sector where firms are rather small. Apprentices often take jobs in different occupations than they are trained for. The leading trainer of bakers in Munich is the Ford Motor Company.

Participation in apprenticeship programs postpones but does not eliminate job shopping. Completion of an apprenticeship, like graduation from a school, often conveys more information about the tenacity of the trainee and his/her ability to finish a task than it does about the quality of the skill learned. Credentialling conveys information about the stamina and degree of socialization of the apprentice that is valued in the market. A recent study of the economic returns to the German apprenticeship program suggests that they are low. ${ }^{\text {lo }}$

The apprenticeship and schooling system in Germany has come under attack as rigid and unresponsive. Students are tracked at an early age. There are many fewer second and third chance features in this system than are characteristic of schooling choices in the United States a feature unlikely to be attractive in an American setting. Although some Realschüler become students at the universities, this occurs infrequently. It is often charged that minorities (especially Turks) are excluded from participation because the informal nature of the workplace places a premium on personal ties as a basis for participating in work groups. Turkish participation rates among eligibles are only a third of German rates.

The very narrow technical training and rigid curriculum of the apprenticeship progran 
may contribute to dicinished options in later life. This observation goes part way toward explaining the current anomaly of low youth unemployment rates and much higher adult unemployment rates found even in the former West German part of Germany.

The German apprenticeship system is a mechanism for evading union-mandated minimum wage laws. It is no accident that those firms permitted to pay the lowest wages (in the crafts sector) are more likely to train apprentices than higher wage - firms in the industrial and commercial sector where the permitted reduction from the standard wage is not as great.

The German apprenticeship system is also a device for permitting choice in schools. By selecting an occupation, a tratinee also selects a school. He/she is thus able to shop around for better schools and better training, thus breaking the monopoly of public schools in Germany at the secondary Ievel.

The exam certification system acts as a credentialling device for young workers. What is not clear is whether the signal sent by the credential represents achievement of real skills or a demonstration of persistence and tenacity. Exams do not certify specific skilis or match specific characteristics, although both matching and firm specific irvestment are important components of modem economies. Indeed, it seems likely that if we were to return to a craft economy, match-specific and firm-specific skills would be even more important than they are today and testing would be even less effective in such an environment.

(iii) Youth Apprenticeship As A Way To Introduce Choice in Schools and A Youth Subminimum Wage

A central prenise of the argument in support of the Youth Apprenticeship Program is that American public schools have failed to provide adequate basic skills and job-oriented 
training for non-college-bound youth. Curfent governmental educational subsidy policies favor college education over other forms of education and training. The vocational training provided by public school bureaucracies is often not tailored to market demands.

Proposals for apprenticeships redress the current imbalance in public expenditure between academic and job-oriented training. In this regard they correct a potentially important distortion in the provision of education although they run the risk of favoring general skills over specific skills. To the extent that proposals for apprenticeships undermine the monopoly of local school bureaucracies in shaping the content of schooling and adapting the curricuhum to market needs, the youth appresticeship movement can be seen as supporting choice in schools by permitting students to opt out of conventional school systems that discourage creativity, achievement or productivity. To the extent that apprenticeships subvent the minimum wage, they expand youth employment, and the opportunities for youth to take training wages from private firms.

Of course, these objectives could be achieved by other means. The minimum wage could be lowered or abolished. Choice could be instituted in schools. Vouchers could open up options for improved training and schooling. Since these policy options do not appear to be acceptable to the new administration, an apprenticeship policy that goes part way toward accomplishing these goais may be a successful partial substitute.

The argument for the Youth Apprenticeship Program is not couched in these terms. Instead, a romanticized description of an "orderly" transition from school to work through workbased training is presented that understates the value of job shopping, and the importance of firm-specific human capital and likely overstates the value of continuous progression through schooling, training, and work. 
It is significant that there is littie hard evidence on the efficacy of any work-based leaming plan. It is also significant that popular discussions fail to note that the compulsory schooling age is higher in Germany than in the U.S. (18 vs 16) and this necessarily reduces unemployment in Germany at young ages. The fact that most youth trained as apprentices work for fims other than the ones that train them means that job shopping is postponed, not eliminated. The stancards of evidence required to justify most government training programs have been suspended for this one.

Once it is recognized that the "Youth Unemployment Problem" is one experienced by a small minority of disadvantaged youth, it seems rather drastic to restructure the training environment for all teenagers to benefit just a few. Targetted programs like Job Corps that are costly but that have proven to be effective may accomplish more than the sweeping reforms of the sort envisaged by some advocates of Youth Apprenticeship programs.

\section{Exidence About Conventional Workfare and Mandatory Welfare Work Programs}

One major campaign promise made by President Clinton was that most persons curently on welfare would be given extensive training and be required to move off welfare within the next two years. It is fair to say that no one believes that this will happen. How effective are curent programs in moving people from work to welfare? In this section, I draw heavily on the work of my University of Chicago colleague, Robert LaLonde. ${ }^{\mathrm{IL}}$

\section{(i) Welfare Women}

Employment and training programs increase the earnings of female AFDC recipients. 
Eamings gains are (a) modest (b) persistent over several years (c) arise from several different treatments and (d) are sometimes quite cost effective. Participation in an Arkansas job search program was required for AFDC recipients with children over age three. Participants attended a group job search club for two weeks and then were asked to search as individuals for an additional two months. A program in San Diego required all AFDC participants to take job search assistance and mandated work expenience. The gains were high for participants in both programs. The Nationai Supported Work program provided intensive training and job search assistance. Roughly $\$ 16,550$ were spent per recipient. However, the estimated rate of return to this program was only $3.5 \%$.

Results from the recent experiment evaluating the Job Training Partnership Act confirm these findings: the largest effects are for women but none of these programs is sufficiently sizeable to move more than a tiny fraction of women out of welfare. These programs are often cost effective (especially if the opportunity cost of trainee time is ignored or is sufficiently low) but do not produce dramatic changes in participant camings. ${ }^{12}$

\section{(ii) Adult Males}

The evidence for this group is consistent. Retums are low but usually positive. Job search is an effective strategy but produces only modest increases in the level of earnings.

\section{(iii) Youth}

Evidence from the JTPA experiment produces only low or negative eamings. For male youth, the estimated negative effect is unbelievably low. If taken seriously, participation in JTPA has a more negative impact on youth earnings than participation in the Ammy, loss of work experience or the cost of incarceration as measured by many studies. ${ }^{13}$ 
Only the Job Corps has a demonstrated positive impact on eamings but it is an expensive program - costing $\$ 20,000$ or so per participant with an estimated return of roughly $8-9 \%$. There is some support for expanding this program. It is a tried and true successful vehicle for job advancement among disadvartaged youth.

\section{(iv) Workfare and LearnFare}

How effective are the recent learnfare and workfare programs? A recent evaluation of two programs conducted in Wisconsin is of interest. One program - Work Experience and Job Training - provided AFDC clients with assessment, job search activities, subsidized employmcnt, job training and community work experience. The second program - Community Work Experience - requires trandatory participation in unpaid community service jobs for non-exempt AFDC participants. Participants who failed to find employment after completing their education and training were also requited to participate in CWEP jobs.

Using randomized trials for one county and nonexperimental methods for the rest, researchers show no effests of these programs compared to existing program alteratives. ${ }^{14}$ The reduction in AFDC participation that is widely cited as a consequence of these programs is essentially due to the improvement in the Wisconsin economy over the past few years. These resuits are disappointing but consistent with previous studies of the efficacy of such programs by the Manpower Demonstration Research Corporation. ${ }^{15}$ Mandatory work experience prograns produce little long term gains. It is just as well that President Clinton has quietly dropped his campaigr pledge to end welfare. No cheap training solution has yet been found that can end the welfare problem. To raise a welfare woman out of poverty by increasing her earnings by $\$ 5,000$ per year ( $\$ 100$ per week) will cost at least $\$ 50,000$. This is the scale of required investment and 
no "quick fix" low cest solution is in sight.

\section{E. Displaced Workers}

Displaced workers suffer major wage losses. This evidence is consistent with an important role for matching-specificity and firm-specific human capital. Programs that successfuily placed displaced workers are expensive. The "iron law" of investment appiles here as well. For each dollar of wage gain, at least ten dollars of investment cost must be incurred.

\section{Faith in Tests To Measure Job Skills}

A centrai tenet in the new consensus is that tests measure job-relevant skills. The case for national testing and credentialling is based on this premise. So is the notion that incentives within education can be restored by linking performance on tests to the quality of job training placements in orcer to tighten the link between academic and nonacademic leaming.

One test of skill has recently been studied: the GED. It is of interest in its own right because a major goal of many govemment job training programs is certification of participants at high school-GED levels.

The GED has become a major source of high school degrees in this country, One out of every seven new high school certificate holders achieve that status by a GED. In New York State and Florida the proportion is one out of four. High school completion levels measured by the proportion of persons age 20-24 who have high school credentials or more - have not deteriorated in the last twenty years only because GED certification has been rising. Advocacy groups - in particular the American Council on Education - claim that it is easy to test for high 
school job relevant skills and to certify them.

What is the market value of this certificalion? Except for a tiny upper tail, GED certified high school graduates eam roughly the same as high school dropouts. Controlling for their years of schooling completed, male GED certificate holders in their late $20^{\circ}$ and early $30^{\circ}$ carn the same as high school dropouts. For other groups of workers over the age range $20-60$ there is little evidence that GED certified workers earn the sarne wages or work the same hours as orcinary high school graduates. ${ }^{16}$

These findings challenge both the wisdom of our current training emphasis on GED certinication, and the folly of relying on tests to measure market-relevant skills. National tests that credential "skill" cannot capture the imagination, drive or motivation of the person being tested nor can they develop a score that will successfully rank its bearer in all firms in the economy. Markets value and humans possess richer and more diverse skilis than can be captured by stancardized exams.

\section{Summary}

This paper assesces recent proposals for job training, workplace education and workfare. The challenges confronting the new administration are daunting. Even a very successful human capital investment strategy - one with a rate of retum as high as 10 parcent - would require trillions of dollars of investment to restore parities in wage differentials by education to their 1979 levels. Small sums like those proposed in the recently defeated stimulus package can go only a little way toward reducing inequality and uplifting the wages of unskilled workers. 
Footnotes

'Revision of The Aloysius Dunaway Memorial Lecture presented at Michigan State University April 15, 1993. Heckman is Henry Schultz Professor of Economics, The University of Chicago and Director, Center For Social Program Evaluation, The Haris School, University of Chicago. Support for this research was provided by a grant from the Lynde and Hary Bradley Foundation of Milwaukce, Wisconsin. The Bradley Foundation does not, necessarily, endorse the view's expressed in this paper. I have received useful comments from Robert LaLonde, Derek Neal, Jeffrey Smith and Rainer Winkelmann.

'See Nathan Glazer, "A Human Capital Policy For The Cities", The Public Interest, Number :12, Summer, 1993, p. 27-49. The main references are America's Choice: High Skills Qr Low Wages issued by the National Cenler on Education and The Economy; Robert Reich's The Work of Nations and Growth With Equity by Martin Neil Batley, Gary Burtless and Robert Litan.

${ }^{2}$ Michael Piore and Charles Sabel, The Second Industrial Divide, Basic Books, New York, 1984.

${ }^{3}$ Stephen Hamilton, Apprenticeship for Adulthood, The Free Press, New York, 1990.

${ }^{4}$ See Barbara Heyres, "Schooling and Cognitive Development: Is There A Season For Leaming?", Child Development, 1987, Vol. 58, pp. 1151-1160.

5See Anatomy of A Demonstration by Gary Walker and Frances Viella-Velez, Public and Privale Ventures, Philadelphia, PA, 1992.

${ }^{6}$ For one statement of this view, see Robert I. Lerman and Hilliard Pouncy, "The 
Compeling Case For Youth Apprenticeship", The Public Interest, \#101, Fall, 1990, pp. 62-77.

'Robert Topel and Michael Ward, "Job Mobility and The Careers of Young Men", Quarterty Joumal of Economics, Vol. 107, May, 1992, pp. 439-480.

${ }^{B}$ Articles on this topic by these authors appear in Richard Freeman and David Wise, eds., The Youth Labor Market: its Nature, Causes and Consequences; University of Chicago Press, Chicago, 1982; Richard B. Fieeman and Hary Holzer, The Black Youth Emplovment Crisis, University of Chicago Press, Chicago, 1986.

${ }^{9}$ Rainer Winkelmann points out to me that these figures may overstate the lack of participation of German firms in the apprenticeship programs because solo entrepreneurs are required to register as firms but are unlikely to use apprerticeships and there are many such entrepreneurs.

${ }^{10}$ Kenneth Couch, "High School Vocational Education, Apprenticeship, and Famings: A Comparison of Germany and United States", forthcoming. Applied Economics Ouarterlys, 1993.

"Robert LaLonde, "The Eamings Impact of U.S. Employment and Training Programs", University of Chicago, January 29, 1992.

${ }^{12}$ Howard Bloom, Lary Or, George Cave, Stephen Bell, Fred Doolittle, "The National JTPA Study: Tite II-A Impacts on Eanings and Employment at 18 Months", Abt Associates, Bethesda Maryland, January, 1993.

${ }^{13}$ The National JTPA study has been fraught with controversey. See the critique of the study by Fred Romero, "The National JTPA Study: Lessons Not Leamed", unpublished manuscript, April 21, 1993, Washington, D.C.

${ }^{14}$ John Pawasara: and Lois M. Quinn, "Evaluation of The Wisconsin WEJT/CWEP 
Welfare Employment Programs", Employment and Training Institute, University of Wisconsin, Milwaukee, April, 1993.

isudith Gueron and Edward Pauly, From Welfare to Work, Russell Sage Foundation, New York, 1991.

${ }^{10}$ See Stephen Cameron and James Heckman, "The Nonequivalence of High School Equivalents", Joumal of Labor Economics, Vol. 1:, No. 1, Part :, January 1993, pp.1-47, and their unpublished manuscript, The GED. 